\title{
Developing Integrity University Governance Model in Indonesia
}

\author{
Salahudin ${ }^{1}$, Achmad Nurmandi ${ }^{2}$, Mukti Fajar ${ }^{3}$, Dyah Mutiarin ${ }^{2}$, Baldric Siregar ${ }^{4}$, Tri Sulistyaningsih ${ }^{1}$, Jainuri ${ }^{1}$, \\ Rendra Agusta ${ }^{5}$, Kisman Karinda ${ }^{6}$ \\ ${ }^{1}$ Government Studies, Universitas Muhammadiyah Malang \\ ${ }^{2}$ Department of Government Affairs and Administration, Jusuf Kallah School of Government, Universitas \\ Muhammadiyah Yogyakarta \\ 3Faculty of Law, Universitas Muhammadiyah Yogyakarta \\ ${ }^{4}$ Sekolah Tinggi Ilmu Ekonomi YKPN Yogyakarta \\ ${ }^{5}$ Consulting Sinergi Visi Utama Yogyakarta \\ ${ }^{6}$ Government Studies, Universitas Muhammadiyah Luwuk \\ Correspondence: Salahudin, Government Studies, Universitas Muhammadiyah Malang, Indonesia. Jalan Raya \\ Tlogomas No. 246, Tlogomas. E-mail: salahudinmsi@umm.ac.id
}

Received: August 3, 2019

doi:10.5430/ijhe.v8n5p185
Accepted: August 21, $2019 \quad$ Online Published: August 24, 2019

URL: https://doi.org/10.5430/ijhe.v8n5p185

\begin{abstract}
This paper aims to explain and design a model for university governance with integrity that is focused on the core and business processes of university organizations. NVivo applacation had been used in this research. This study revealed that universities have not shown governance with integrity. The colleges have not established the values of integrity as key content at the core of their business and the business processes of a university, namely education, research, society services, human resource management, budgeting, cooperation, infrastructure, and leadership. Furthermore, corruption practices in university governance have been widespread. Therefore, by using method of Strategic Analysis Surfacing and Testing (SAST), this paper also formulates a model of university governance with integrity that puts emphasis on strengthening the core and business processes of university organizations and strengthening the organizational values of university institutions including culture, norms, regulation, management, and organizational structure.
\end{abstract}

Keywords: university governance, integrity, corruption, institution, management

\section{Introduction}

The management of a university with integrity is a challenge for the government and the managers in Indonesia, as well as communities around the world. The term integrity has moral and ethical connotations and it does not only depend on individuals, but also on the context of a university as an institutional organization (Bretag, 2013). Integrity is uniquely human (Milton, 2015) and it cannot be separated from relations among humans. Cheating behavior carried out by a student at the college is a simple example of this if examined further. It is not only about the individual behavior of the student but is also influenced by the institutional management of the university (Sayidah et al., 2019). In context, several universities in the world are trying to answer this challenge, as can be seen from several previous studies (Ison, Borman, Dowling, \& Ison, 2014; Mirshekary \& Lawrence, 2009).

Studies conducted in Serbia, Croatia, Bulgaria, and Moldova have found that corruption has been a common symptom in admissions, grading, and housing (Heyneman 2007). From this perspective, Heyneman (2007), a researcher concerned with corruption issues in universities, classified previous studies by Hallak \& Poisson (2008), Heyneman, (2007) and Washburn and Gottesman (2010), who tried to map the types and influencing variables of these symptoms. From the study and based on media news sources in the USA, Russia, and the UK, it was found that forms of corruption were based on state conditions and other types that were universal. In the USA, the problem of college integrity regarded issue including fraud, plagiarism, and violence, but in Russia, this was more focused on bribery in the registration process (Dobbins and Knill, 2017).

A comprehensive study of university governance with integrity in Indonesia has not yet been done (Utama \& Utama, 2014). However, every year there are cases of corruption practices in Indonesian universities. Tthese cases spread to 
the public. Indonesia Corruption Watch (ICW) undertook observations from 2006 to August 2016, and there were at least 37 corruption cases related to universities with 12 patterns of corruption, such as corruption in the procurement of goods and services that became the most widely used mode, corruption of funds for student research and scholarship funds, corruption practices using bribery patterns, corruption in the universities internal budget, corruption of the sale of assets owned by universities, and corruption of the Student Education Development Assistance Fund (SPP) (Indonesia Corruption Watch, 2016).

Indeed, the Indonesian government has been managing the university governance with integrity by implementing a number of regulations, namely: 1) Presidential Instruction number 9 of 1977 concerning Operation Control (1977-1981), tasked with cleaning up illegal levies, controlling stealth money, and regulating local government officials and the department; 2) The Presidential Regulation of the Republic of Indonesia number 87 of 2016 concerning the Net Sweep Task Force, promulgated on October 21, 2016; and 3) Decree of the Minister of Research, Technology and University of the Republic of Indonesia number 350/M/Kemenristek/2016 concerning the Task Force for Clean Sweep of Illegal Levies in the Ministry of Research, Technology and University. However, the corruption practices in university governances run massively (Siaputra et al., 2015). Therefore, a model of integrity university governance needs to built by exploring university governance problems based on university stakeholder's perceptions. According to the problems, university governance model can be arranged reflecting integrity values. This paper tries to answer the research question which is: What are the integrity problems in Indonesian universities? What is a suitable governance model for ideal academic integrity in the Indonesian context?

\section{Literature Review}

\subsection{University Governance with Integrity}

A University is an organization consisting of the Senate, university leaders, faculty, and courses, each of which has the power to exercise its authority. As an organization, the universities primary mission is to improve the effectiveness of governance through structural reforms (Christensen, 2011). Governance refers to how the entity acts can collectively decide policy and strategy (Kaplan, 2004). The OECD formulated the synthesis of governance or governance formula as follows:

'The structures, relationships, and processes through which, at both national and institutional levels, policies for tertiary education are developed, implemented and reviewed. Governance comprises a complex web including the legislative framework, the characteristics of institutions, and how they relate to the whole system, how money is allocated to the institutions and how they are accountable for the way it is spent, as well as less formal structures and relationships that steer and influence behavior (Organisation for Economic Co-operation and Development [OECD] 2003).

Understanding the above statement combines structure, relationships, and the process that is started. In the world of university governance, it also refers to the structures and processes of an academic institution in achieving balance between control and influence (Washburn and Gottesman, 2010). This understanding comes from the perspective of neo-institutionalism that views universities as a network of complex organizations. It is driven by interactions between individuals and units with the capability and power of the cognitive and orientation of the normative, respectively within the institutional framework and external situation specifically. Following this perspective, Washburn and Gottesman (2010) distinguished governance into two types. First, hard organization '(rational section) refers to structures, regulation, and the sanction system, with organizational processes to ensure adherence (compliance) to policies and procedures. Second, soft governance (interactional) includes social system connections and interactions within the organization to develop and maintain the individual and group norms.

Furthermore, integrity is the values, attitudes, and behavior of various aspects of college honesty. More than using institutional theory, the manifestation of the importance of honesty raised the gradation of the level of regulation to the level of culture. The college has structure and regulations with the ability to create rules and supervise a match between the rules of behavior and sanctions, and the rewards to its members (Christensen, 2011). Moreover, the college has a normative pillar consisting of dimension values and norms prescriptive, evaluative, and liabilities. Pillar culture is values, attitudes, and behaviors of honesty that are not only carried out as a duty, but also as a social habit (Christensen, 2011). Kaplan (2004) describes the organizational practices that are not otherwise traditional rituals and norms. Heyneman (2007) by using the theory of institution, also makes the gradation level of institutionalization to be the value of honesty in college starting from (a) reform of the structure to reduce the potential for corruption, (b) improved management, (c) measures to prevent corruption, and (d) sanction.

According to the elaboration above, university governance with integrity can be formulated as the structure and 
process of a university where the policy in the field of education, research, community service development, implementation and review that is relatively supported by the system, and social interactions within or outside the organization, based on the norms of honesty. The implementation gradation values of honesty in college follows the pattern of the lowest level being S (structure), then M (management), R (regulative), N (norm), and C (culture) (Dobbins \& Knill, 2017).

\subsection{Corruption Practices in University Governance}

Governance of universities with integrity faces severe challenges in various parts of the world. Sawyer et al. (2006) analyzed the phenomenon of 'corporatization' (p. 11) in which universities with structures, such as companies, make decisions in the field of education and administration, often profit driven rather than for intangible values, such as academic integrity and truth. Universities in Chile could become an example for the relationship between governance and lack of morals in university institutions (Leihy \& Salazar, 2017). Corruption is the most fundamental problem in university governance and corruption practices in education, especially in colleges, are not a new phenomenon (Gilmore MEd et al., 2010). The phenomenon of corruption in a university is common and occurs in many countries, especially in developing countries (Heyneman, 2007). The researcher noted that corruption in the management of university systems in various countries takes place in a variety of ways. For Brazil in particular, this includes corruption governance of human resources through the withdrawal of money from a prospective faculty and staff who want to become permanent employees and lecturers at a college. Furthermore, in Indonesia, corruption takes place in the form of faculty roles which require students to pay thesis fees (ghost teacher). In the Philippines, the phenomenon of corruption occurs in the distribution and procurement of textbooks Hallak \& Poisson (2008).

Corruption practices in universities continue to have a negative impact on their governance and the human resources in a country, including low public confidence in the college, poor quality of education, low competitiveness of scholars and the nation's youth, and the erosion of national values within a culture of corruption across generations (Hallak \& Poisson 2008; Heyneman, 2007). The modes of corruption that occur in university institutions include extra tuition fees for graduate student's courses, additional fees for activities of institutional visits, delay or absence of lecturers in lecture hours, extortion from faculty to students, the payment of administrative fees for borrowing books, and the maintenance of course grade and diplomas being legalized. Siaputra et al., (2015) examined the academic integrity of universities in Indonesia explicitly. Siaputra et al., (2015) found that the governance of a university was still marred by acts of academic violations committed by lecturers, invigilators, staff employees, and students.

Corruption can be made through the actions of student's cheating on tests, where a student is in the process of undertaking a test subject and is trying to find and take advantage of an opportunity to open/review notes related to the exam (Bretag, 2013). If a student fails to cheat, they could then take more corruptive actions and meet professors to ask for 'wisdom', so as to receive a passing grade (Gallant, 2017). Corruption practices in colleges continue massively, so this phenomenon is very dangerous for the existence of the state. The aspect of corruption in a university also indicates that educational institutions are not free from corruption, even though colleges are educational institutions aimed to make and shape the culture of the nation's dignity and integrity(Macfarlane, Zhang, \& Pun, n.d; Palanski \& Yammarino, 2009).

Table 1. Taxonomy on corruption practices in university governance

\begin{tabular}{ccc}
\hline $\begin{array}{c}\text { University Governance } \\
\text { Areas }\end{array}$ & Corruption practices & Reference \\
\hline $\begin{array}{c}\text { Education and } \\
\text { Teaching }\end{array}$ & Bribery: & (Orkodashvili, 2011) \\
- & $\begin{array}{c}\text { Students pay writing service task subjects and } \\
\text { the final project (thesis and dissertation). } \\
\text { Lecturer forcing students to give bribes to the } \\
\text { faculty in order to facilitate the learning } \\
\text { process. }\end{array}$ \\
& Lecturer forcing students to pay fees for \\
& additional assistance for students who score \\
below the passing standard.
\end{tabular}




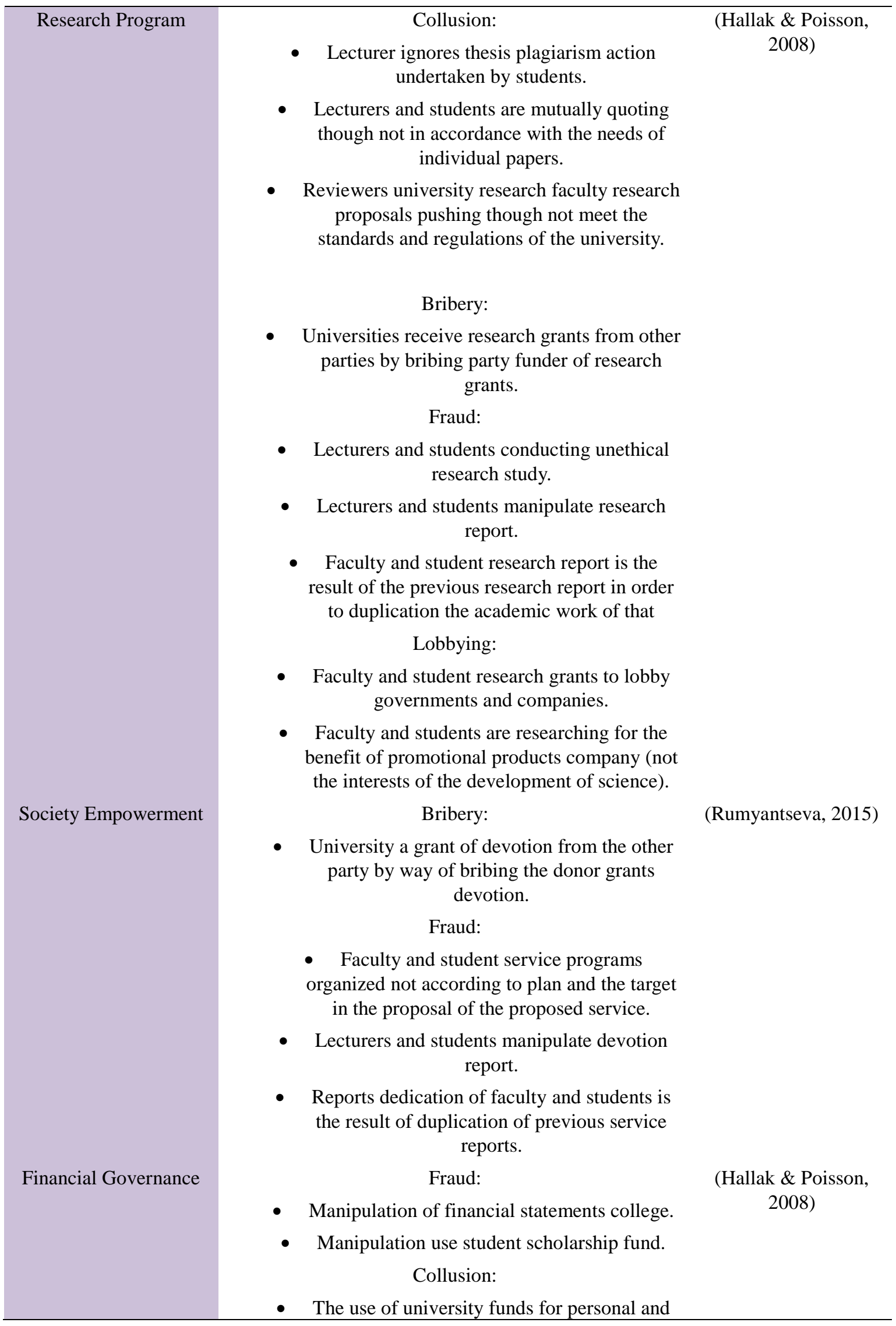




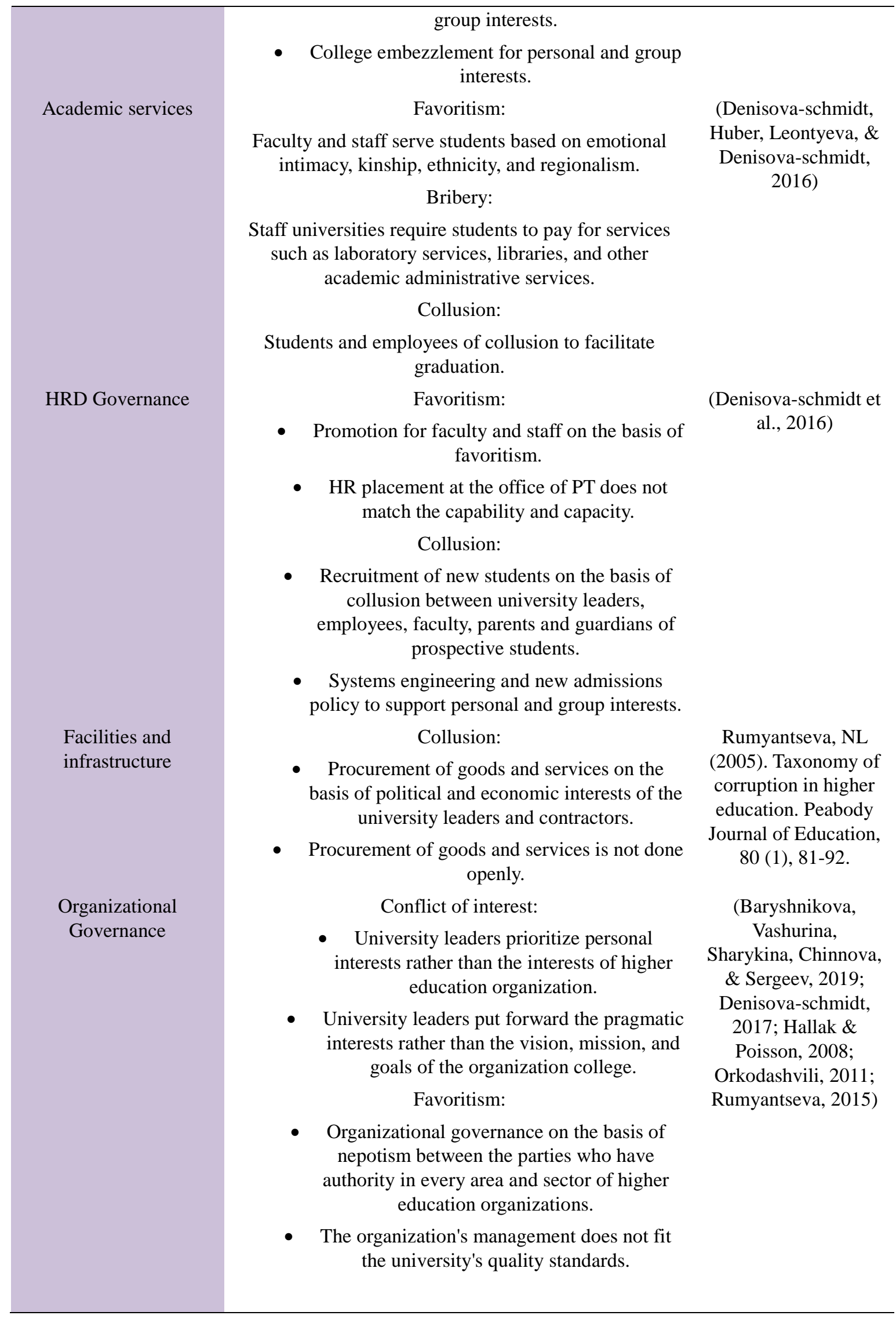




\begin{tabular}{|c|c|c|}
\hline Leadership & $\begin{array}{l}\text { Evolving doors: } \\
\text { - } \quad \text { Government officials intervene politically in } \\
\text { the rector elections. } \\
\text { - } \quad \text { College leadership model was not built in a } \\
\text { democratic and fair. }\end{array}$ & $\begin{array}{c}\text { (Baryshnikova et al., } \\
\text { 2019; Hallak \& } \\
\text { Poisson, 2008; } \\
\text { Orkodashvili, 2011; } \\
\text { Rumyantseva, 2015) }\end{array}$ \\
\hline Cooperation & $\begin{array}{l}\text { Fraud: } \\
\text { - } \quad \text { College runs a cooperation agreement with } \\
\text { the other parties honestly. } \\
\text { - Manipulation of cooperation for the benefit } \\
\text { of the accreditation document. }\end{array}$ & \\
\hline
\end{tabular}

The taxonomy of types and corrupt practices in the governance of universities in table 1 shows that corruption in higher education is a form of governance of higher education that is not integrity in the field of education and teaching, research, service, governance of human resources, financial governance, academic services, infrastructure, organization, leadership, and cooperation. Therefore, the definition of corruption in higher education is different from the definition of corruption in general, which showed the practice of abuse of power and authority for personal interests related to the budget (state finance). Corrupt practices in higher education are not only related to the budget of the college but also related to the sale and purchase value, plagiarism, cheating, buying and selling scientific work of lecturers to students.

\section{Method}

This study used a qualitative research approach and was conducted through six stages, namely literature, preparation of models of governance of college integrity, validation of models and instruments by the manager of the college, the revision of models and instruments, model validation, and instruments by the regulator, and the drafting of a regulation model and instrument as shown in Figure 1 below

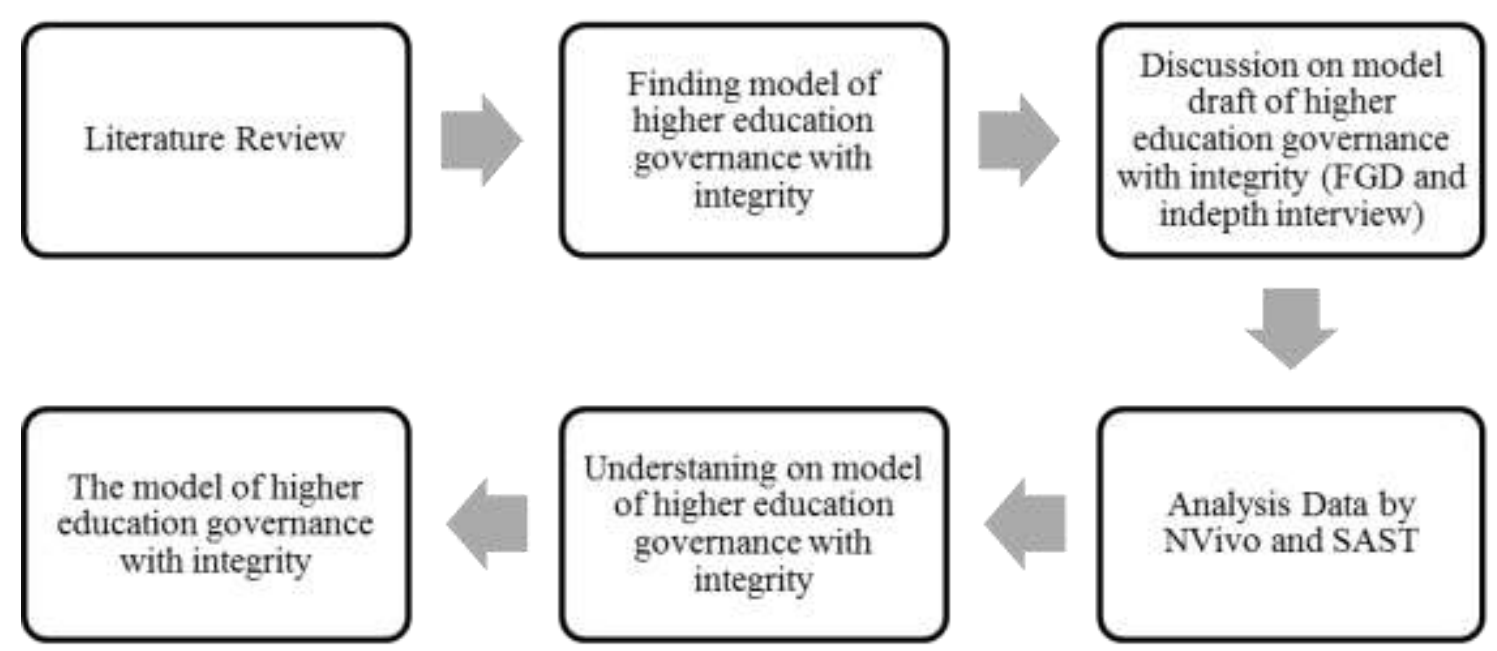

Figure 1. Research process

Data from this study were collected using several methods as follows: interview, focus group discussion (FGD), questionnaire, and documentation. Interview questions were based on the literature reviews and data of college governance issues exposed in the media that answers the research questions. The interview questions addressed to key informants were determined by purposive sampling. Key informants were selected from the questionnaire respondents who occupied important positions and roles as well as researchers and observers of higher education governance in Indonesia. The key informants interviews are the Rector of Universitas Islam Negeri Pontianak, Vice Dean of the Faculty of Agriculture of Universitas Tanjungpura, researchers on college integrity of Universitas Tanjungpura, Head of General Administration of Universitas Muhammadiyah Pontianak, Head of the General Administration of Academic Politeknik Pontianak, Vice Rector for General and Financial of Politeknik Pontianak, former rector of Universitas Muhammadiyah Surakarta, five lecturers and researchers governance of higher 
education of Universitas Gadjah Mada, a professor of law of Universitas Muhammadiyah Yogyakarta, a commisioner of Corruption Eradication Commission of Indonesia, two researchers of the Corruption Eradication Commission of Indonesia, five researchers for PUKAT (Center for the Study of Anti Corruption/Pusat Studi Anti Korupsi), and five researchers for GEMATI (Movement Transparency community for Indonesia/Gerakan Masayarakat untuk Transparansi Indonesia).

FGD has been conducted in three cities that are Solo City, Pontianak City, and Yogyakarta City. Three of the cities are area of state Higher Education in Indonesia. Most Indonesian people come to the area to take higher education degree. Three of the cities have lot of scientists in different fields, NGO activist on education advocations, and mass media. However, there are some cases that they have not shown integrity values in higher education governance (Indonesia Corruption Watch, 2016). Therefore, FGD was implemented in the cities. Participants of FGD are the official members of state higher universities of Indonesia who are from the University of Gadjah Mada (HR Director, Dean of the Faculty of Economics and researcher governance of universities integrity), the Director of Graduate State University Yogyakarta, vice Rector for Human Resources and Finance of University Tanjongpura Pontianak, Rector of Pontianak State Islamic University, Rector of the State University of Sunan Kalijaga, Vice Rector of Academic Affairs University of Surakarta, Lecturer of Indonesia Surakarta Institute of Arts, and the Rector of the Politeknik Pontianak. Moreover, the partcipants of FGD are NGO Activists related to higher education governance that are PUKAT director (the Center for Anti-Corruption Studies /Pusat Studi Anti Korupsi) and director GEMATI (Social Movement for Transparency of Indonesia /Gerakan Transparansi untuk Masyarakat Indonesia).

Before the implementation of FGD, authors of this paper arranged paper draft that are consist of higher education integrity model, some cases on low integrity of higher education governance, and questionnaire on the higher education integrity indicators. The paper draft was given to the members of FGD. The participants of FGD read the paper draft before FGD has been conducted in the three cities. The study also used data documents related to the governance of higher education namely accreditation and report documents of college performance and the performance of lecturers from the University of Gadjah Mada, Yogyakarta State University, University of Tanjongpura Pontianak, State Islamic University in Pontianak, State University Sunan Kalijaga, State University of Surakarta, Indonesia Surakarta Art Institute, and Polytechnic Pontianak, research report documents of higher education governance of NGOs PUKAT and GEMATI, and news / information on governance issues college in the print media and online media.

Determination of 165 respondents conducted by purposive sampling, in which respondents have been selected based on roles, knowledge, and experience in the areas of governance and colleges. Details of 165 respondents were 20 university leaders (rectors, vice-rectors, directors of bureau chief of public and private universities), 10 researchers areas of governance colleges, 30 lecturers, 40 staff college, 45 students from public and private universities, and 20 NGO activists college governance areas. Total respondents were drawn proportionally from the three regions of 33\% of the city of Yogyakarta, 33\% of the city of Solo, and 33\% from Pontianak, Indonesia. Of the 165 respondents, 125 respondents fill and return the questionnaires, in which 125 respondents were 15 university leaders (rector, vice chancellor, director, and head of state and private university bureaus), 10 researchers in university governance, 20 lecturers, 30 university staff, 40 students from state and private tertiary institutions, and 10 NGO activists in the field of university governance.

Among the 125 respondents were selected 15 key informants. Key informants were taken based on roles, knowledge, and experience in the field of higher education governance. Key informants of this study are Rector of Universitas Islam Negeri Pontianak, Vice Dean of the Faculty of Agriculture of Universitas Tanjungpura, researcher on university governance with integrity of Universitas Tanjungpura, Head of Public Administration of University of Muhammadiyah Pontianak, Head of the General Administration of Academic of Politeknik Pontianak, Vice Rector for Public Affairs and Finance of Politeknik Pontianak, former rector of Universitas Muhammadiyah Surakarta, 5 lecturers/researchers of university governance of Gadjah Mada University, a lecturer of law for Universitas Muhammadiyah Yogyakarta, two researchers at the Corruption Eradication Commission, five researchers for PUKAT (the Center for Anti-Corruption Studies/Pusat Studi Anti Korupsi), and five researchers for GEMATI (Social Movement for Transparency of Indonesia/Gerakan Masyarakat untuk Transparansi Indonesia).

This research used Nvivo 12 plus application to analyze the data FGD, interviews, and documentation. NVivo application is one of the qualitative research data analysis application that has been used by many qualitative researchers around the world (Sotiriadou, Popi, Brouwers, Jessie, Le, 2014). This application helps researchers visualize and categorize data FGD,interviews, and documentation. Furthermore, to develop models of university governance with integrity needs to use the method of Strategic Analysis Surfacing and Testing (SAST). SAST carried 
out through the application of FGD, interview, documentation, deployment and filling the questionnaire and the analysis of the results of the questionnaire.

Focus group discussion and interview were conducted to identify the problems of governance university based on opinions, knowledge, and experience of university stakeholders. The problems identified in FGD,interview, and documentation were analyzed using NVivo 12 plus. Problems identified so-called strategic issues related to the governance of the college integrity. The strategic issue used as a basis for constructing a questionnaire was filled by 125 respondents and analyzed using the method of Strategic Analysis Surfacing and Testing (SAST) that is to obtain a degree of certainty and the interests of the strategic assumptions formulated earlier and who had poured into the questionnaires filled out by 125 respondents from college in three regions (Solo, Yogyakarta, and Pontianak).

\section{Results}

\subsection{The Integrity Problems of Indonesian Universities}

One of the crucial problems of university governance in Indonesia is that most of the universities have not obtained the values of integrity as part of university governance. There are several issues related to college governance integrity where corruption practices are running into academic affairs, such as education and teaching programs, research projects, and the social services program. These academic corruption actions are not only related to money but also to the context of sexuality, in which academic staff make academic and public services for students easier. Conversely, the students may instead make sexual advances on the staff. Moreover, other integrity issues of university governance include the manipulation of data for institution accreditation, plagiarism, cheating, markup research, social service project funds, and other matters.

In general, corruption of Indonesian universities includes the embezzlement of funds for student scholarships, Corporate Social Responsibility fund, grants, internal funds of the university, and research funding. In addition, corruption in other forms is also prevalent in Indonesian university governance, such as gratification, fake diplomas, license to study programs, buying and selling of diplomas, selling value, manipulation of student funds, transactions in the election of the rector, bribery for new admissions, transactional in the procurement of goods and services, and manipulation of fund asset sales in a university. Based on data from the 105 news (online and print media) from January 2014 until December 2017 were found types of corruption in Indonesian universities as figure 2.

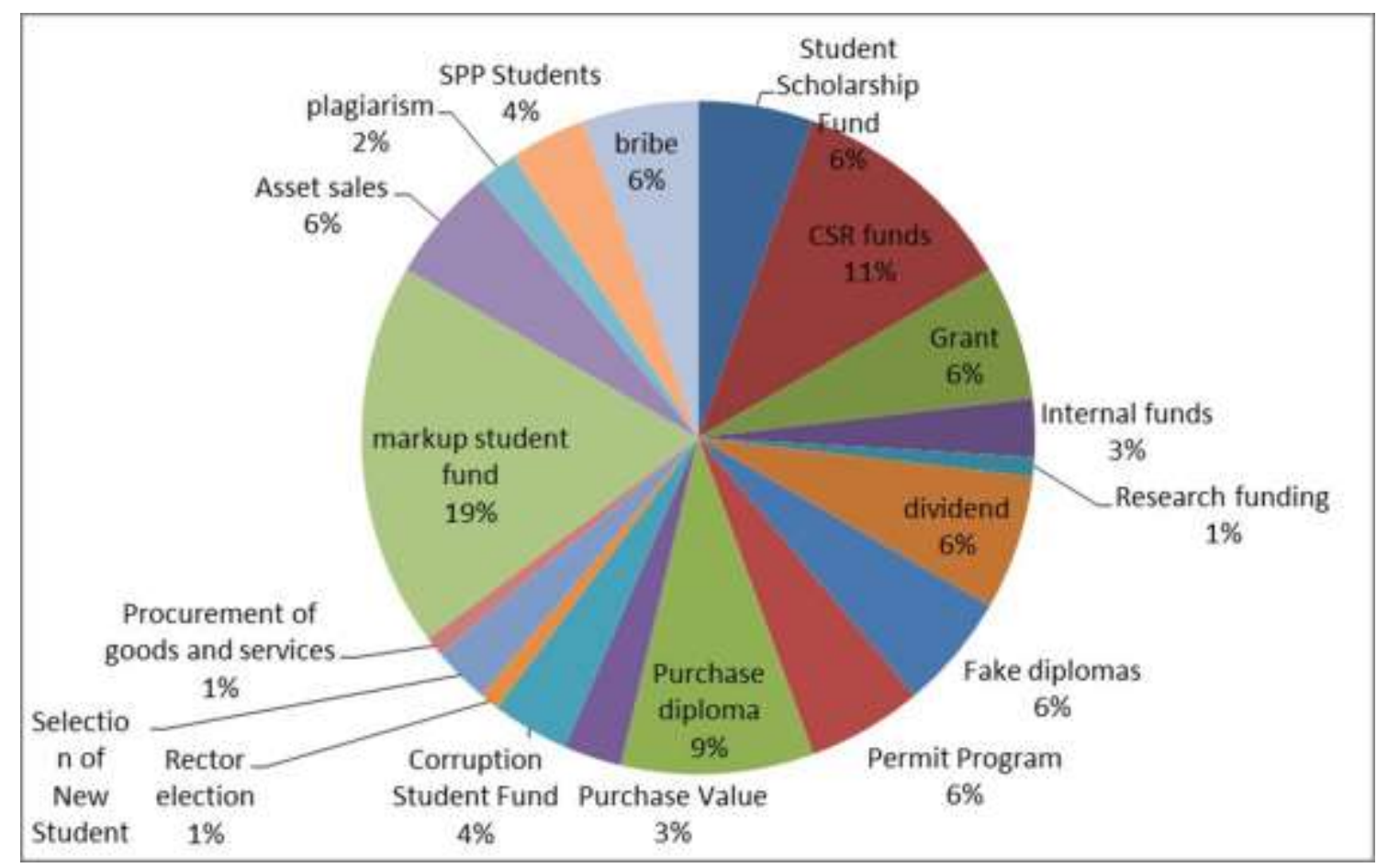

Figure 2. Types of corruption in Indonesian universities

Based on the above data, the practice of buying and selling of diplomas is common in most universities in Indonesia, where a university sells certificates to the those who require them through data manipulation of lectures, student identity, and a study of students so that the diplomas sold are considered legal. Moreover, corruption in universities 
was also common in the procurement of goods and services, where procurement was done on a transactional basis between the university and the private sector. The corruption practices taking place are both massive and systematic. The data at least described a lack of integrity in the practices of a college. FGD with PUKAT (the Center for Anti-Corruption Studies/Pusat Studi Anti Kotupsi) and GEMATI (Social Movement for Transparency of Indonesia/Gerakan Masayarakat untuk Transparansi Indonesia) revealed some practices of big corruption in Universities, for example, related to 'Buy Flag'. This corruption mode is where the name of an institution (company $\mathrm{X})$ is used to conduct a study in name only, without undertaking the study process.

Furthermore, another form of corruption is the concealment of posted salaries. This mode has long been practiced, for example, pricing tickets for Garuda then replacing them with cheaper airlines or using the railways. This practice in which there would be a Time Results of Operations (SHU) that would be divided among the researchers only, is less when the work is done by an assistant. By the UGM (Universitas Gadjah Mada), using patterns of indirect costs, this would be known at assistant level only, namely for tax cuts. If there were inefficiencies, these would go to the agency, not the residual term. Another corruption behavior occurs usually in the form of deposited funds financing patterns that were performed using a self-managed system, this form of corruption is a way to enter into the activities of staff, once the entire staff deputies come in to the committee (FGD in University of Gadjah Mada, 2018).

Furthermore, FGD in Solo shows that there is corruption in the governance of higher education in Indonesia. The participants reveal the kinds of corruption in higher education among them corruption research grants and devotion, bribes go to college, buying and selling value, duplication of research, conflicts of interest college leaders, the deviant behavior of teaching staff (lecturers), corruption, administrative costs of service academic, and manipulation of financial statements. Then, FGD in Pontianak city also showed the same problem that there is corruption in college. The participants in Pontianak emphasis on academic, administrative corruption such as bribe to go to college, cutting research costs by university leaders, and conflicts of interest college leadership.

Then, the analysis NVivo against FGD in Yogyakarta, Solo, and Pontianak revealed that corruption in higher education takes place in the form of administrative corruption universities, corruption research grants and publications, corruption education funds, conflict of interest, lack of professionalism governance of universities, and corruption of college development. The fifth form of corruption is a serious concern of the FGD like NVivo analysis visualization results shown in Figure 3. Visualization NVivo as in figure 3, illustrates that there is a density of attention FGD against corruption and dedication to research grants, college administrative corruption, and corruption education. The attention density shows that FGD participants that there have been very serious corruption in the field of research, publications, education, and university administration affairs in Indonesia. Then, the FGD participants also considered that the lack of professionalism of university governance, conflicts of interest and corruption of development funds are also part of the corruption in higher education should be handled seriously.

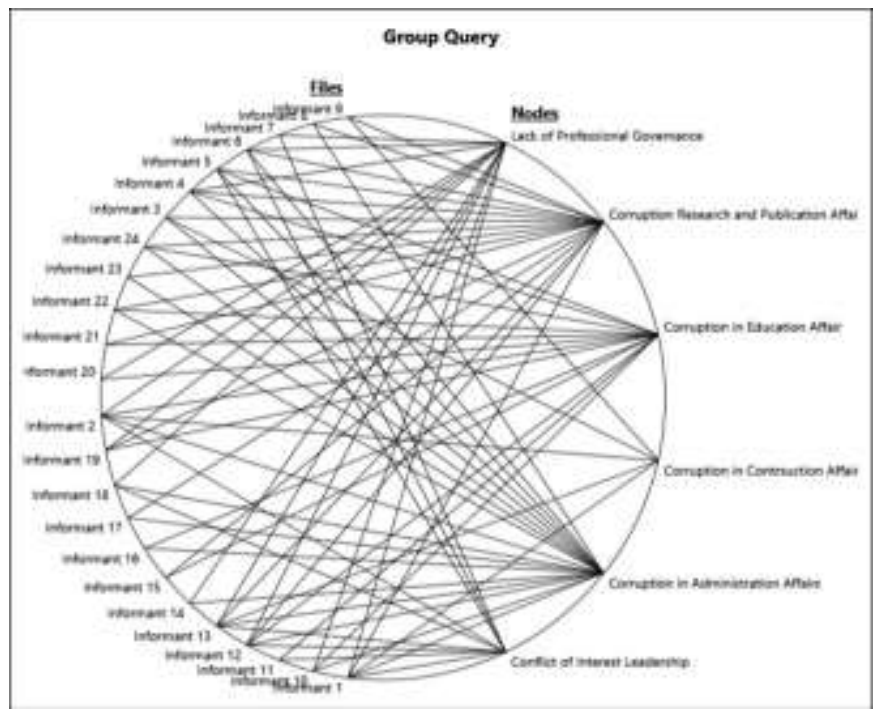

Figure 3. Group Analysis NVivo 12 plus 
Image visualization NVivo 12 in figure 3 above can be mapped quantitatively in the form of a matrix coding radar analysis NVivo 12 as follows.

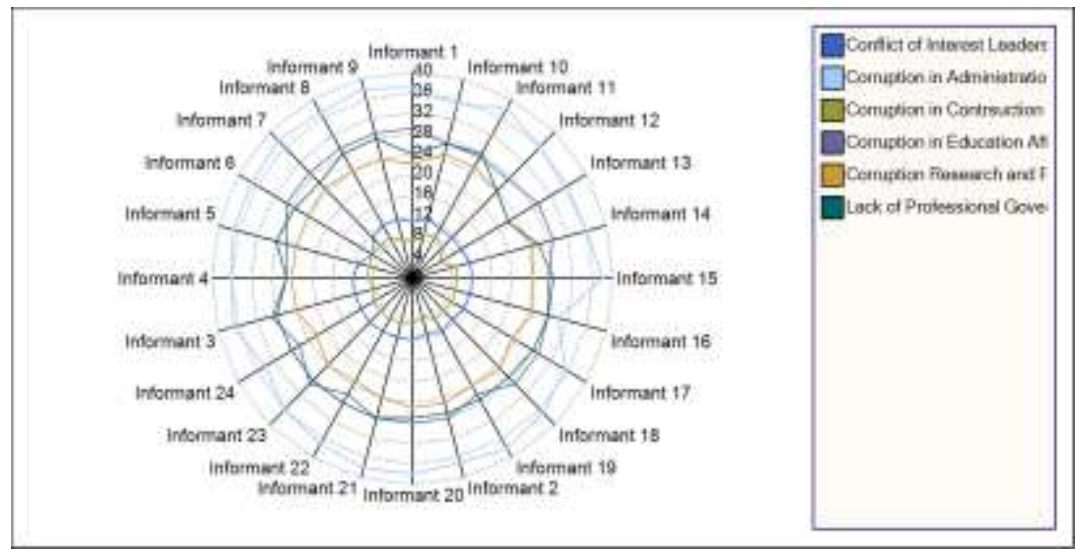

Figure 4. Matrix coding of analisis NVivo 12 plus

In line with the analysis visualization NVivo 12 previously described above (figure 3), the coding matrix analysis NVivo 12 as in the figure 4 also revealed the extent of the problem of corruption in higher education which is measured using a scale of 4-40. 4-40 scale shows the level of informant ratings of several corruption issues in college. The higher the number the higher the scale indicates informant ratings to the problems of corruption and bad governance of the college. The results of the analysis of NVivo 12 as in figure 4 above shows that corruption academic administration (scale 36), corruption in education affairs (scale 28), the low professionalism of governance of higher education (scale 24), and corruption in research grant (scale 20) are the corruption that often occurs in college in Indonesia. Even though conflict of interest (scale 12), and corruption of constructions (scale 8), the areas also needs policy priority of university stakeholders to support university governance with integrity.

\subsection{Design a Suitable Model of College Governance with Integrity in an Indonesian Context}

Based on the results of the focus group discussion (FGD), expert interviews by in-depth interview, and Nvivo analysis as above, the fundamental problem with university governance is a lack of stakeholder commitment to a college in order to realize college governance with integrity in ten areas, such as education and teaching, research, community service, human resources governance, financial governance, infrastructure, academic services, leadership, organization, and cooperation. Impact of stakeholders' low commitment is corruption running massively in higher education in the form of administrative corruption universities, corruption research grants and publications, corruption education funds, conflict of interest, lack of professionalism governance of universities, and corruption of college development. This paper has tried to develop a college governance model of integrity, which refers to the issue of governance of universities in Indonesia. Also, the model design was based on an approach of the analysis of certainty and the interest variable of the governance of the affairs of university that were considered important by the stakeholders of the college. Analysis of certainty was conducted to understand the parts of college governance which impact on the good and bad governance of a college. In other ways, the analysis of interest was to understand the college governance areas that impact on the good and bad governance of a university. The degree of certainty and the interest analysis can be seen in the chart below (Figure 5). 


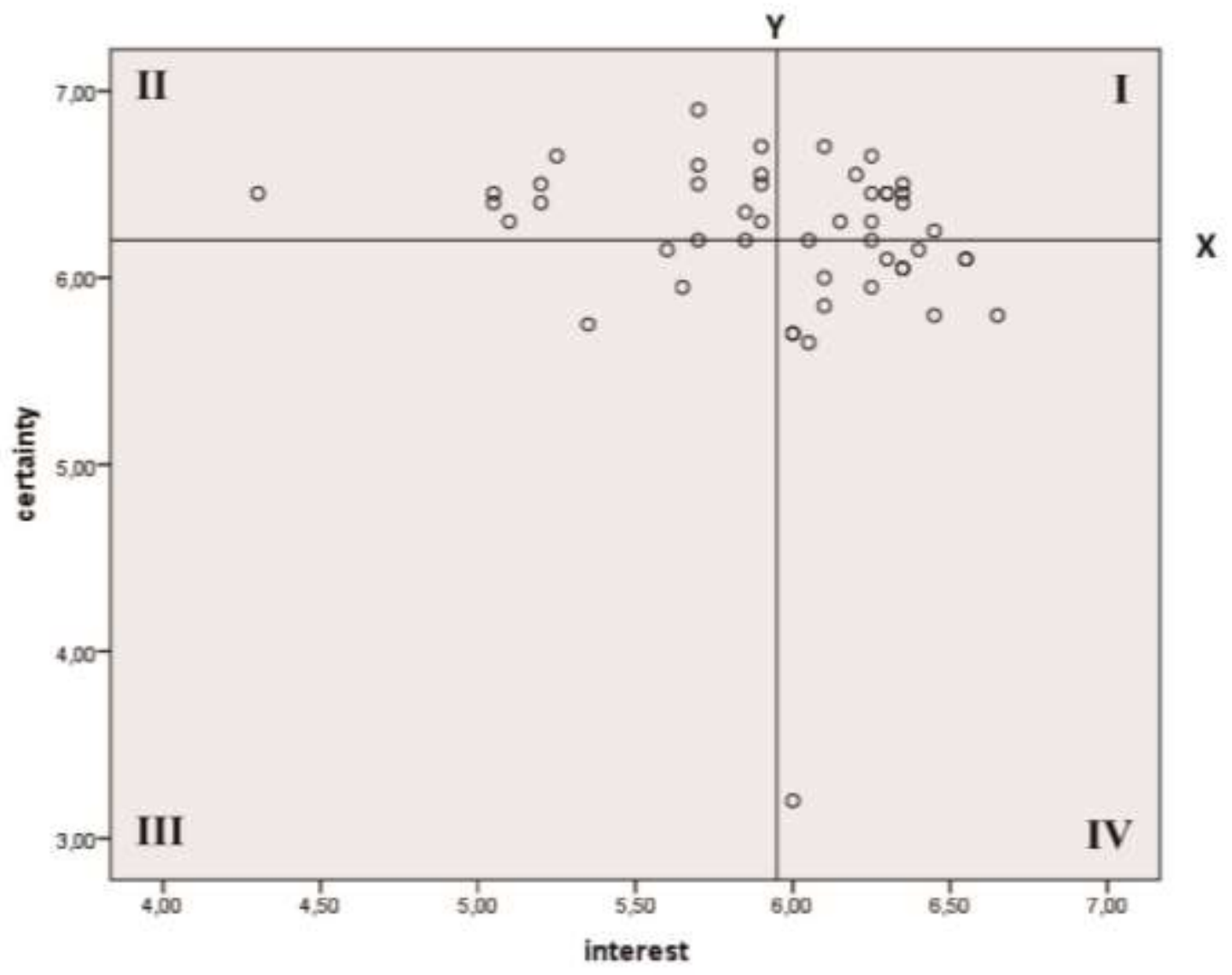

Figure 5. The degree of certainty and interest graph for university governance with integrity

Assumptions for Quadrant I: there are 10 areas that have a degree of certainty and a high level of interest to the establishment of university governance with integrity (y: 6.00-7.00). Assumptions for Quadrant II: there are five areas that have a low degree of certainty $(x: 4.50-6.00)$ and five areas the high level of interest (y: 6.00-7.00) towards the establishment of the university governance with integrity. Assumptions for Quadrant III: there are three areas that have high levels of certainty and a low level of interest towards the establishment of the college ( $x$ : 5.50-6.00 and $y$ : 5.50-6.00). Assumptions for the quadrant IV: there are five areas that have a high degree of certainty $(x: 6.00-7.00)$ and 5 area of importance is low (y:5.50-6.00) on the formation of university governance with integrity. Based on the analysis, stakeholders of Indonesian universities focus on ten areas of university governance that have high score in certainty and interest supporting university governance with integrity as in table 2 below.

Table 2. Interest and certainty variables of university governance

\begin{tabular}{clll}
\hline No & Ten areas of University Governance & Certainty & Interest \\
\hline 1 & Education and Teaching & 6,33 & 6.70 \\
2 & Community service & 6.93 & 6.70 \\
3 & Research & 6.95 & 6,64 \\
4 & Management Infrastructures & 6.42 & 6,31 \\
5 & Academic Administrative Services & 6.51 & 6,18 \\
6 & Organization & 6.25 & 6.13 \\
7 & Leadership & 6.28 & 6.08 \\
8 & Financial Governance & 6.43 & 6.06 \\
9 & Cooperation & 6,15 & 5.72 \\
10 & Human Resources Governance & 5.54 & 5.35 \\
\hline
\end{tabular}


Table 2 above also confirms that the assumption was positioned in the establishment of governance model colleges of integrity that is ten areas of governance colleges integrity: education and teaching, community service, research, infrastructure management, academic services, organization, leadership, budget management, cooperation, and human resource management is a strategic area of concern in building college governance system integrity. This analysis was based on the results of questionnaires on certainty and interests, as indicated by the stakeholders of the college. It consisted of variables filtered with a degree of certainty as well as the high interests of each area of governance of a uiversity.

Therefore, this paper considers that universities need regulatory support, structure, management, and norms as a culture (Christensen, 2011). Four main elements must support the implementation of the values of integrity in a university: 1) Creation of regulations support the planting of integrity values (regulation); 2) enforcement of integrity as the norm (norm); 3) strengthening the management of the planting of integrity values (management); and 4) creating a culture that supports the internalization of the values of honesty, fairness, and professionalism (culture) (Kaplan, 2004). Through the five primary elements, university governance with integrity can be realized gradually.

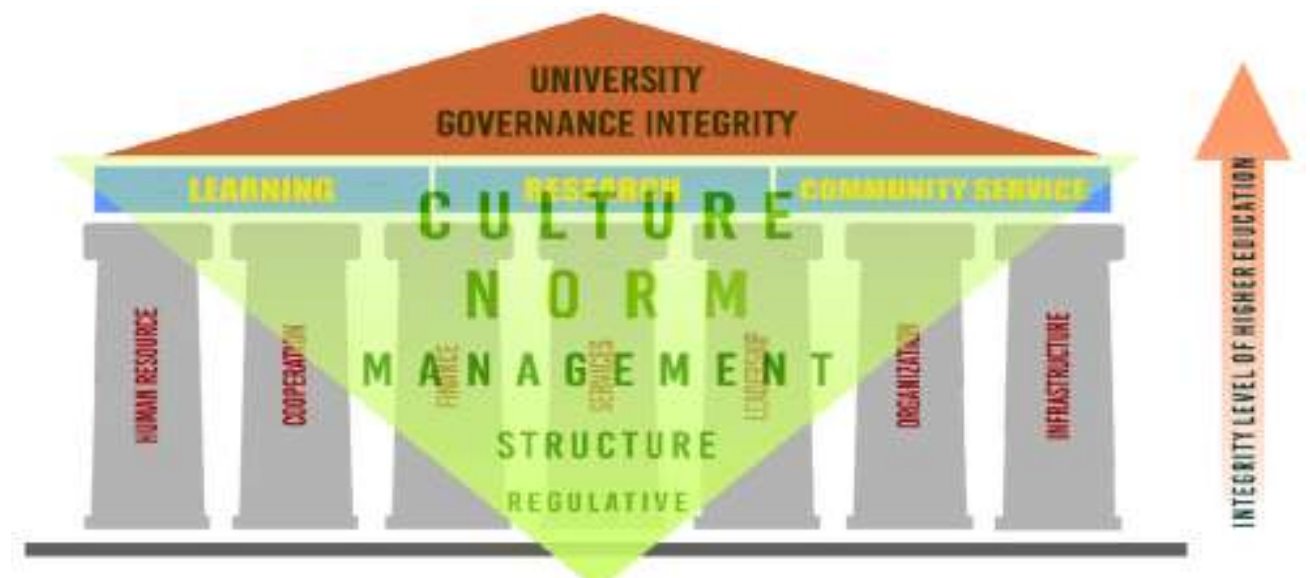

\section{HI GHER E D U C ATIDN AFFAIRS}

Figure 6. Model of Indonesian university governance with integrity

The model above (figure 6) describes ten areas of college governance with integrity that are an integral part of single unitary university management divided into two major elements of core business and supporting system (Dobbins and Knill, 2017). In this case, Dobbins \& Knill (2017) explained a scope of university governance that included businesses and core supporting systems as a buffer for college governance. The core business of the universities quality management includes education and teaching, research, and dedication. Moreover, supporting the college management system includes human resources management, financial governance, infrastructure, academic administrative services, organizations, leadership, and cooperation. Therefore, a university governance model of integrity can be focused on core structuring and the supporting system of university management. Governance and supporting the core business of the college system place values of integrity, such as honesty, professionalism, and fairness, in supporting the realization of college integrity (integrity of university) (Heyneman, 2007; and Milton, 2015).

\section{Discussion}

Evidence from this research clearly identifies that university governance is faced with several problems that make a university unable to achieve governance with integrity. The fundamental problem is that corruption runs deeply within the colleges. Corruption practices in a university occur in various ways, such as misappropriation of grant funds, purchase of diploma certificates, selling the value of courses and thesis, manipulation of program reporting on research and service, plagiarism, bribery, budget corruption in scholarships, leadership selection that is not procedural, the arrangement of human resources that is not professional, and employee recruitment that is not consistent. Based on the Nvivo analysis, there are five corruption forms of Indonesian universities that are corruption in academic administration affairs, corruption in research and publication, corruption in education program, lack of professional in university governance, and corruption in university building construction affairs.

Corruption in academic affairs is corruption done by the staff and university leaders concerning academic services. In this regard, staff and university leaders in providing services to students in a discriminatory manner. The best service 
is given to students who have a close relationship with staff and the top leadership of the university. These findings reinforce the findings of research carried out by Denisova-schmidt et al. (2016) and Orkodashvili (2011), where both of them in different studies revealed the existence of collusion and nepotism in the academic services at the college. Later, corruption and dedication to research funds also occur at universities in Indonesia. In this case, faculty and university leaders to use the funds for the benefit of research and dedication to others, cutting and markup fund research and service. Corrupt practices also run in fund research and service in some countries such as Argentina, Peru, and Uganda. Hallak \& Poisson (2008) said that corruption fund research and service in college is a common practice at universities in Argentina, Peru, Uganda, Africa.

One of the corrupt practices is also common in universities in Indonesia, namely corruption education in the form of bribery and trading value between faculty and students. Denisova-schmidt et al. (2016) revealed that corruption in higher education takes place in the form of bribery between faculty and students, plagiarism, and strengthening additional cost to students outside of the provisions in force. Orkodashvili (2011) also find their collusion and nepotism among the faculty and students in the determination of grades and graduation. Heyneman (2007) revealed that in colleges Also, there was corruption in the selection of new students, the accreditation of the college, the implementation of research programs, and service programs. Ison et al. (2014) also revealed the most significant issue of corruption in colleges was corruption in the form of plagiarism, copying, duplication of research reports, purchase value, and bribery.

Then, the other corrupt practices in higher education in the form of lack of professionalism governance of universities and the markup college building fund. Baryshnikova et al. (2019) revealed that the mode of corruption in college together with the mode of government corruption and the politicians in government institutions such as markup project, gratuities, and kickbacks among stakeholders. The mode also occurred at the college. Corruption in the form of conflict of interest also coloring any decision-making in higher education (Hallak \& Poisson, 2008).

The results of SAST analysis and calculation Cartesian quadrant in this study as described previously insisted that the five corruption form are corrupt practices taking place in the ten areas of governance universities namely: the five corruption cases can be explained into ten areas: education and teaching, research, service, human resources, finance, facilities and infrastructure management, academic administrative services, leadership, organization, and cooperation. The findings of this research confirm that the governance of universities in Indonesia shows the university governance with integrity yet.

Therefore, developing a model for university governance with integrity needs to be focused on these ten areas of university governance. The implementation of integrity values in university governance must be supported by four main elements: 1) making regulations that support the planting of integrity values (regulation); 2) strengthening the management of planting integrity values (management); 3) enforcement of integrity as the norm (norm); and (4) creating a culture that supports the internalization of the values of honesty, fairness, and professionalism (culture). Through these five primary elements, university governance with integrity can be realized gradually. The results of the analysis confirms Washburn and Gottesman's (2010) assertion that university governance improvement should be focused on managing institution values, such as structures, regulation and the sanction system, organizational processes, individual behavior, and group norms.

Heyneman (2007) argued that the strategy for realizing college governance with integrity and reducing the risk due to corruption in university were: First, reformation of university structures. In this regard, universities must design a structure that minimizes the emergence of an independent institution for exam courses and final projects, an independent agency for an accredited college, independent agency to issue license accreditation, a policy of college ownership being institutionalized, and the separation of educational affairs from the college business unit. Second, reformation of university management is through an arrangement of university institutions involving professional organizations, with public and independent institutions supervising college performance. Third, preventive action to evaluate and monitor the performance of leadership, faculty, staff, and students, to enforce the code of ethics on leaders, faculty, staff, and students, report cases of corruption, create a system of financial transparency, create and strengthen media publication as a tool of control, and implement anti-corruption education involving an anti-corruption agency. Fourth, placing sanctions against are the perpetrators of corruption in a college. Enforcement of sanctions would have to be done through criminal sanctions for the perpetrators of corruption by professionals in universities, publishing the names of the criminals and dismissing the perpetrator due to the criminal behavior.

Indeed, there were differences between the findings of this study and the results of the analysis of strategies to realize university governance with integrity compiled by Heyneman (2007).For instance, the focus of the study conducted by Heyneman (2007) was for a strategy to realize a college governance of integrity against extraordinary acts of 
corruption. Whereas, the focus of this research was governance and supporting the core business college system as seen from the perspective of the fundamental values of integrity (not only from the perspective of corruption). Second, Heyneman (2007) divided the strategy of realizing a university with integrity into four parts that consisted of reforming the structure, management, enforcing norms, and giving sanctions to perpetrators of corruption. The strategies by Heyneman (2007) are a non-comprehensive strategy in realizing a university with integrity, as the objective of the strategy does not reach the level of effort to include the internalization of integrity values in university governance (Denisova-schmidt et al., 2016).

Shortly, this paper emphasizes that ten areas of governance can be used as objects of attention for stakeholders to realize college governance with integrity. Also, these ten areas are used as objects of assessment by university institutions with integrity, where stakeholders can measure the integrity of a university by seeing and understanding the governance of all ten areas that cover the core business and support the university system.

\section{Conclusion}

This paper reveals that corruption in universities has been taking place in five corruption namely in the form of academic affairs administration, corruption in research and publication, corruption in education program, less professional in university governance, conflict of interest, and corruption in construction affairs. The five corruption runs in the ten governance areas that are: 1) Education and teaching, 2) study, 3) community service, 4) management of human resources, 5) financial governance, 6) infrastructure, 7) academic services, 8) leadership, 9) the organization, and 10) cooperation. Corruption is not only related to embezzlement of a college, but also associated with the buying and selling of diplomas, grades, plagiarism, cheating, markup projects, and extortion. The corrupt practices show that university governance has not become a form of integrity. In that case, it needs a model of university governance that emphasizes strengthening the core and business processes of a college.

The core business of a college covers education, research, and service. While college business processes consist of human resources, budget, information technology, service, leadership, infrastructure, cooperation, organization, core, and business processes that need to support college organizational values among the college culture, norms, regulation, management, and the organizational structure which must support the implementation or realization of university governance with integrity. Therefore, the model describes the overall integrity of college grades and activities of the organization in which the core, process, and values are integrated in one unified system of governance for a college. The application of the model requires goodwill from stakeholders directly related to the university world.

\section{Acknowledgements}

We would like to thank rector of Universitas Muhammadiyah Malang, Director of Jusuf Kalla School of Government, Universitas Muhammadiyah Yogyakarta, Anti Corruption Comission, Republic of Indonesia.

\section{References}

Baryshnikova, M., Vashurina, E., Sharykina, E., Chinnova, I. \& Sergeev, Y. (2019). The Role of Flagship Universities in a Region:Transformation Models. Voprosy Obrazovaniya / Educational Studies Moscow, (1), 8-43. https://doi.org/10.17323/1814-9545-2019-1-8-43

Bretag, T. (2013). Challenges in Addressing Plagiarism in Education. PLoS Medicine, 10(12), e1001574. https://doi.org/10.1371/journal.pmed.1001574

Christensen, T. (2011). University governance reforms : potential problems of more autonomy? Higher education, (123), 503-517. https://doi.org/10.1007/s10734-010-9401-z

Denisova-schmidt, E. (2017). The Challenges of Academic Integrity. Retrieved from https://www.bc.edu/content/dam/files/research_sites/cihe/pubs/CIHE Perspective/Perspective, 2017 No cropsFINAL.pdf

Denisova-schmidt, E., Huber, M., Leontyeva, E. \& Denisova-schmidt, E. (2016). Do Anti-Corruption Educational Campaigns Reach Students? Evidence from two cities in Russia and Ukraine. Вопросы образования, 2016 https://doi.org/10.17323/1814-9545-2016-1-61-83

Dobbins, M. \& Knill, C. (2017). Higher education governance in France, Germany, and Italy: Change and variation in the impact of transnational soft governance. Policy and Society, 36(1), 67-88. https://doi.org/10.1080/14494035.2017.1278868

Gallant, T. B. (2017). Academic Integrity as a Teaching \& Learning Issue : From Theory to Practice Academic 
Integrity as a Teaching \& Learning Issue: From Theory to Practice. Theory Into Practice, 56(2), 88-94. https://doi.org/10.1080/00405841.2017.1308173

Gilmore MEd, J., Strickland, D., Timmerman, B., Maher, M. \& Feldon, D. (2010). Weeds in the flower garden: An exploration of plagiarism in graduate students' research proposals and its connection to enculturation, ESL, and contextual factors. () International Journal for Educational Integrity, 6(1), 13-28. Retrieved from http://www.ojs.unisa.edu.au/journals/index.php/IJEI/

Hallak, J. \& Poisson, M. (2008). Corrupt schools, corrupt universities: What can be done? International Institute for Educational Planning. https://doi.org/10.1080/03057921003703934

Heyneman, S. P. (2007). Three universities in Georgia, Kazakhstan and Kyrgyzstan: The struggle against corruption and for social cohesion. Prospects, 37(3), 305-318. https://doi.org/10.1007/s11125-008-9037-2

Indonesia Corruption Watch. (2016). Korupsi di Perguruan Tinggi. Retrieved from https://www.antikorupsi.org/id/news/korupsi-di-perguruan-tinggi

Ison, D. C., Borman, G. D., Dowling, N. M. \& Ison, D. C. (2014). Does the online environment promote plagiarism? A comparative study of dissertations from brick-and-mortar versus online institutions. Journal of Online Learning \& Teaching, 10(2), 272-281. https://doi.org/10.1007/s10805-015-9233-7

Kaplan, G. E. (2004). Do governance structures matter? New Directions for Higher Education, 2004(127), 23-34. https://doi.org/10.1002/he.153

Leihy, P. \& Salazar, J. M. (2017). The moral dimension in Chilean higher education's expansion. Higher Education, 74(1), 147-161. https://doi.org/10.1007/s10734-016-0034-8

Macfarlane, B., Zhang, J. \& Pun, A. (n.d.). Studies in Higher Education Academic integrity: a review of the literature, (August 2012), 37-41. https://doi.org/10.1080/03075079.2012.709495

Milton, C. L. (2015). Ethics and Academic Integrity. Nursing Science Quarterly, 28(1), 18-20. https://doi.org/10.1177/0894318414558620

Mirshekary, S. \& Lawrence, A. D. K. (2009). Academic and business ethical misconduct and cultural values: A cross national comparison. Journal of Academic Ethics, 7(3), 141-157. https://doi.org/10.1007/s10805-009-9093-0

Organisation for Economic Co-operation and Development. (2003). Changing Patterns of Governance in Higher Education. Education Policy Analysis, 59-78. https://doi.org/10.1787/epa-2003-en

Orkodashvili, M. (2011). Corruption, Collusion, and Nepotism in Higher Education and the Labor Market in Georgia. European Education, 43(2), 32-53. https://doi.org/10.2753/eue1056-4934430202

Palanski, M. E. \& Yammarino, F. J. (2009). Integrity and leadership: A multi-level conceptual framework. The Leadership Quarterly, 20(3), 405-420. https://doi.org/10.1016/j.leaqua.2009.03.008

Rumyantseva, N. L. (2015). Taxonomy of Corruption in Higher Education. Peabody Journal of Education, 80(January 2005), 81-92. https://doi.org/10.1207/S15327930pje8001

Sawyer, K. R., Johnson, J. \& Holub, M. (2006). The Necessary Illegitimacy of the Whistleblower. Ssrn, 1-21. https://doi.org/10.2139/ssrn.917316

Sayidah, N., Ady, S. U., Supriyati, J., Sutarmin, S., Winedar, M., Mulyaningtyas, A. \& Assagaf, A. (2019). Quality and University Governance in Indonesia. International Journal of Higher Education, 8(4), 10. https://doi.org/10.5430/ijhe.v8n4p10

Siaputra, I. B., Santosa, D. A., Surabaya, U., Timur, J., Surabaya, U. \& Java, E. (2015). Academic Integrity Campaign in Indonesia, Handbook of Academic Integrity, (2014), 1-9. https://doi.org/10.1007/978-981-287-079-7

Sotiriadou, Popi, Brouwers \& Jessie, Le, A. (2014). Choosing a qualitative data analysis tool: A comparison of NVivo and Leximancer. https://doi.org/https://doi.org/10.1080/11745398.2014.902292 Copyright

Utama, C. A. \& Utama, S. (2014). Corporate governance, size and disclosure of related party transactions, and firm value: Indonesia evidence. International Journal of Disclosure and Governance. https://doi.org/10.1057/jdg.2013.23

Washburn, R. S. \& Gottesman, M. E. (2010). Transcription termination maintains chromosome integrity. Proceedings of the National Academy of Sciences, 108(2), 792-797. https://doi.org/10.1073/pnas.1009564108 